\title{
A new species of Melanotopelia (Graphidaceae) from Africa
}

\author{
Emmanuël SÉRUSIAUX, A. Maarten BRAND, \\ Eberhard FISCHER, Dorothee KILLMANN, \\ Pieter P. G. van den BOOM and Damien ERTZ
}

\begin{abstract}
Melanotopelia africana is described as new to science from Rwanda (continental Africa) and La Réunion (Mascarenes archipelago). Topeliopsis muscigena is here reported for the first time from La Réunion.
\end{abstract}

Key words: Topeliopsis, Thelotremataceae, Nyungwe Forest, Parc national de La Réunion

\section{Introduction}

Recent detailed morphological and chemical studies have greatly improved the taxonomic knowledge of two large and widespread (especially in tropical areas) families of lichens, for example, the Graphidaceae (Staiger 2002) and the Thelotremataceae (Frisch 2006; Frisch \& Kalb 2006a). Several new genera have been described and old and disused generic names have been resurrected. However, molecular phylogenetic studies, based on parsimony analysis and Bayesian tree sampling of sequences of several genes support only in part the circumscription of many genera, and their relationships are poorly resolved (Staiger et al. 2006; Mangold et al. 2008a). Furthermore, Mangold et al. (2008a) found no support for the distinction of the two families, and thus reduced the Thelotremataceae into synonymy

E. Sérusiaux: Plant Taxonomy and Conservation Biology Unit, University of Liège, Sart Tilman B22, B-4000 Liège, Belgium. Email: E.Serusiaux@ulg.ac.be

A. M. Brand: Klippenwerf 5, NL-2317 DX, Leiden, The Netherlands.

E. Fischer and D. Killmann: Institute for Integrated Natural Sciences, Department of Biology, University of Koblenz-Landau, Universitätstraße 1, D-56070 Koblenz, Germany.

P. P. G. van den Boom: Arafura 16, NL-5691 JA, Son, The Netherlands.

D. Ertz: National Botanical Garden of Belgium, Domaine de Bouchout, B-1860 Meise, Belgium. with the Graphidaceae. These molecular phylogenetic studies clearly demonstrate that many of the commonly used characters are homoplasic and either represent conservation of plesiomorphic characters in different clades, or parallel evolution. Nevertheless, several genera such as Acanthotrema, Chroodiscus, Glyphis, Phaeographis and Platygramme, are strongly supported by morphological and molecular studies.

The genus Topeliopsis was introduced by Kantvilas \& Vězda (2000) to accommodate species of the Thelotremataceae with urceolate or almost perithecioid ascomata, a proper exciple fused with lateral paraphyses, and hyaline, non-halonate, large, muriform ascospores that turn reddish or purple in iodine (Mangold et al. 2008b). As already highlighted by Kantvilas \& Vězda (2000), the genus as delimited was heterogeneous, and was revisited by Kalb (2001) and Frisch \& Kalb (2006b). Their work found strong support in a maximum parsimony and bayesian analysis by Mangold et al. (2008b) and two genera can be distinguished: Topeliopsis Kantvilas \& Vĕzda with 8 species (incl. $T$. azorica, see Coppins \& Aptroot 2008) and Melanotopelia Lumbsch \& Mangold with 2 species; T. meridensis being of uncertain position and possibly related to Chapsa.

During recent field studies, a further species of Melanotopelia was found in Rwanda and La Réunion. It differs from the 
other two species assigned to this genus and is described as new in this paper.

\section{Materials and Methods}

Morphological characters were studied on dry specimens using a dissecting microscope. Anatomical characters were measured under light and interference contrast microscopy on hand-cut sections and squash preparations mounted in water. An aqueous solution of $\mathrm{KOH}(10 \%)$ and lactophenol-cotton blue were used for detailed observation of asci and hamathecial elements. Amyloidy of the tholus of asci and hymenium was tested with Lugol's solution. The analysis of secondary metabolites was performed using TLC, with solvents C and G (Orange et al. 2001); the reagent for the visualization of spots was sulphuric acid sprayed over the plates, followed by heating at $110^{\circ} \mathrm{C}$ for approximately 5 minutes.

\section{The Species}

\section{Melanotopelia africana Sérus., $M$. Brand, Ertz, Eb. Fischer, Killmann \& van den Boom sp. nov.}

\section{Mycobank: MB512925}

Differt ab $M$. rugosa ascomatis minoribus cum superficiei non 5-6-rugosi et poro terminale valde minore. Haec species $M$. toensbergii ex America boreo-occidentali in forma et magnitudine ascomatorum similis sed praesentiam acidi stictici et constictici et absentiam acidi protocetrarici valde differt.

Typus: Rwanda, Southern Province, Nyungwe National Park, Rwasenkoko swamp, along the road Butare-Cyangugu, S 02³1'29.4" E 29²0'26.6", c. 2350 m, pristine Erica thickets, on Erica johnstonii, 28 September 2006, E. Fischer \& E. Sérusiaux (LGholotypus; BG-isotypus).

(Fig. 1A, B \& E)

Thallus crustose, invading corticolous bryophytes or growing directly on bark, whitish grey to pale orange brown when dry, more vivid orange when moistened, not delimited, usually continuous. Photobiont a species of Trentepohlia with cells angular-rounded, 12-20 × 5-8 $\mu \mathrm{m}$.

Ascomata sessile or slightly immersed in the substratum, usually single and not aggregated, subglobose or barrel-shaped, 0.4$0 \cdot 5(-0 \cdot 6) \mathrm{mm}$ diam., $0 \cdot 15-0 \cdot 2(-0 \cdot 25) \mathrm{mm}$ high, at first black and closed and eventually opening through its apical, central 'ostiole' and finally with a terminal pore $c .50-100 \mu \mathrm{m}$ wide and a pale brown, pinkish or almost greyish, irregular, slightly but distinctly swollen and denticulate margin, rarely slightly pruinose; disc hardly seen in mature stages through the pore, deeply and persistently urceolate. Excipulum 30-60 $\mu \mathrm{m}$ wide, cupular, opaque black-brown, $\mathrm{K}-$ and $\mathrm{N}-$, with an internal layer of abundant, perpendicular short paraphyses, 10-20 $\mu \mathrm{m}$ thick. Hypothecium hyaline, $10-15 \mu \mathrm{m}$ thick. Hymenium 100-200 $\mu \mathrm{m}$ thick, hyaline, without epihymenial zone. Paraphyses numerous, simple, c. 1.5 thick, not inflated at their apices. Asci subcylindrical (some becoming inflated when fully mature ascospores are still inside), of the Ostropales-type (thin-walled, with an easily distinguished tholus and a small ocular chamber, I-), 100-170 × 10-15 $\mu \mathrm{m},(1-) 2$ spored. Ascospores ellipsoid, hyaline, muriform, I+ slightly reddish, not halonate, 130 $160 \times 30-45 \mu \mathrm{m}$ when fully mature and ejected.

Conidiomata not found.

Chemistry. Stictic and constictic acids, and related compounds detected by TLC (all collections from Rwanda and one collection from La Réunion tested).

Ecology and distribution. Melanotopelia africana was first found in the Nyungwe Forest in Rwanda (now a National Park), one of the most species-rich montane forests in Africa (Ewango 2002; Fischer et al. 2003; Fischer \& Killmann 2008). Melantopelia africana has been found in two different localities and habitats in the Nyungwe Forest: a) on trunk of Erica, in pristine Erica johnstonii thickets and low forest with Hagenia abyssinica and Rapanea melanophloeios, in the Rwasenkoko swamp and b) just under the summit of Mt Bigugu, on Erica johnstonii and Podocarpus latifolius trunks in dense thickets of E. johnstonii, within a montane forest dominated by $P$. latifolius with Psychotria mahonii, Syzygium guineense and Apodytes dimidiata. In La Réunion, whose habitat diversity has recently been assessed by Strasberg et al. (2005), M. africana has been 

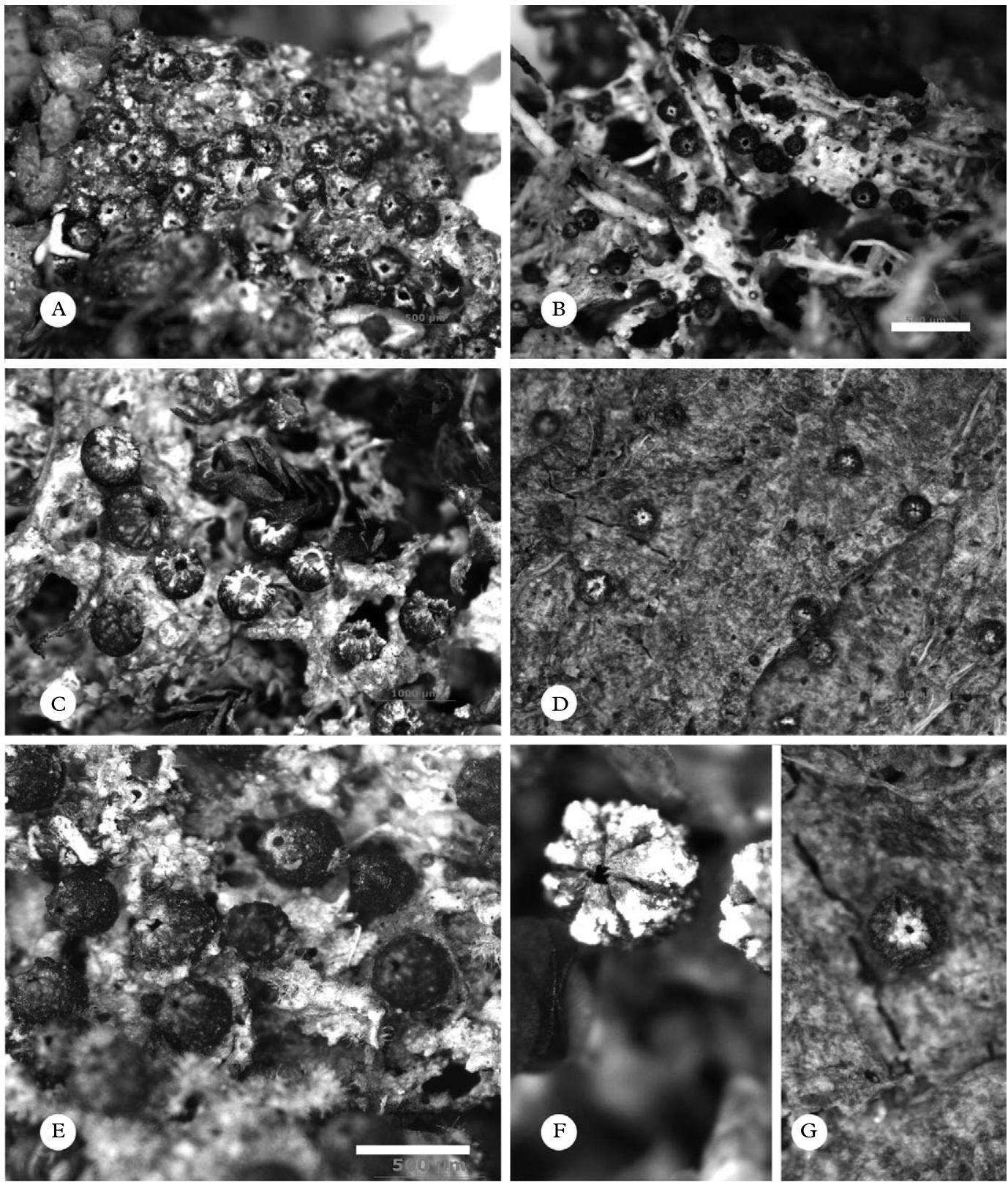

FIG. 1. Melanotopelia species, habitus. A \& E, M. africana (holotype); B, M. africana (La Réunion, Forêt du Grand Matarum, 21 v 2008, M. Brand, E. Sérusiaux, P. van den Boom s . n., LG); C \& F, M. rugosa (G. Kantvilas 444656, $\mathrm{HO}$ ); D \& G, M. toensbergii (isotype LG). Scales. A-D = $1 \mathrm{~mm}$; E-G $=500 \mu \mathrm{m}$.

found in several different habitats: a) on isolated trees in a disturbed habitat by a picnic place, in the submontane windward forest zone, b) on a tree trunk (e. g. Nuxia verticil- lata) in the "Bois de couleurs des hauts" in the montane leeward forest zone, and c) on a trunk of Erica in "Avoune" wet, subalpine shrubland. 
Notes. This species matches perfectly the description of Melanotopelia Lumbsch \& Mangold (Mangold et al. 2008b), i.e. black perithecioid ascomata with a denticulate pore, inner part of the excipulum with numerous, perpendicular paraphyses, muriform, thin-walled ascospores reacting I+ slightly reddish. The previously described species are easily distinguished. Melanotopelia rugosa (Kantvilas \& Vězda) Lumbsch \& Mangold (fig. $1 \mathrm{C} \& \mathrm{~F}$ ) has larger ascomata (up to $0.8-1.0 \mathrm{~mm}$ wide), a much larger terminal pore and 5-6 longitudinal and white pruinose wrinkles over the ascomata surface (easily seen in young ascomata); a species known only from Australia/Tasmania (Kantvilas \& Vězda 2000). Melanotopelia toensbergii (Vězda \& Kantvilas) Lumbsch \& Mangold (fig. 1D \& G), which has similar ascomata but produces protocetraric acid in its thallus versus substances in the stictic acid group for $M$. africana and $M$. rugosa; a species known from the coasts of Western North America (Kantvilas \& Vězda 2000; Breuss 2000).

During this study, material of Topeliopsis from many parts of the world has been examined. As a result, we suggest that Ramonia monospora Aptroot (described from Papua New Guinea and so far known only from the type collection, Aptroot et al. 1997) represents a further species of the Topeliopsis muscigena group. Topeliopsis muscigena is here reported for the first time from La Réunion (present checklist available at www.biologie. uni-hamburg.de/checklists/lichens/africa/france _reunion_l.htm (visited on Jan. 2nd, 2009).
Specimens examined. Rwanda: same locality as the type, 31 iii 2005, D. Ertz, E. Fischer, D. Killmann, E. Sérusiaux s. n. (LG); ibid., 2007, D. Ertz 10950 \& E. Fischer (BR); Nyungwe National Park, track to Mt Bigugu, under the summit, S 02 $26^{\prime} 26.9^{\prime \prime} \mathrm{E}$ $29^{\circ} 15^{\prime} 0.92^{\prime \prime}, 2800 \mathrm{~m}, 20$ ix 2006, dense thickets of Erica johnstonii on gentle slope, E. Fischer, A. Hambuckers, E. Sérusiaux s. n. (LG); ibid., 2007, D. Ertz 11070 \& E. Fischer (BR).-La Réunion: Grand Etang (NE of

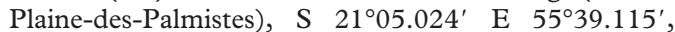
planted trees around the picnic area, $540-550 \mathrm{~m}, 29 \mathrm{v}$ 2008, M. Brand, E. Sérusiaux, P. van den Boom s. n. (LG, REU); Cirque de Cilaos, Forêt du Grand Matarum, S $21^{\circ} 07.416^{\prime}$ E $55^{\circ} 28.983^{\prime}$, heavily disturbed montane forest ("Bois de couleur des hauts"), 1400-1450 m, $21 \mathrm{v}$ 2008, M. Brand, E. Sérusiaux, P. van den Boom s. n. (LG); Forêt de Bébour, trail from main road, just $\mathrm{N}$ of Col de Bébour, to Cassé de Takamaka, 1340 m, 2008, P. van den Boom 40343 \& 40355 (hb. van den Boom); ibid., track from the "Gîte" to Caverne Dufour, S $21^{\circ} 05.102^{\prime}$ E $55^{\circ} 31.362^{\prime}$, low shrub with Erica arborescens and E. montana, with enormous carpets of pleurocarpous mosses and Sphagnum on the ground, $1900 \mathrm{~m}$, 2 vi 2008, M. Brand, E. Sérusiaux, P. van den Boom s. n. (LG).

Specimens of other species examined. Melanotopelia toensbergii: USA: Washington: Olympic National Park, Lake Ozetten W of Ozette River, N 48 $09^{\prime}$ W $124^{\circ} 40.5^{\prime}$, $10-15 \mathrm{~m}$, on Thuja plicata in oldgrowth, coniferous forest, 1998, T. Tønsberg 25545 (LG-isotypus).

Melanotopelia rugosa. Australia: Tasmania: The Sentinels, c. $2 \mathrm{~km} \mathrm{~S}$ of old Pedder Track rest area, S $42^{\circ} 53^{\prime} \mathrm{E} 146^{\circ} 12^{\prime}, 800 \mathrm{~m}$, in moist, very sheltered rock crevices, on soil and peat, 1991, G. Kantvilas 444656 (HO).

Topeliopsis muscigena. La Réunion: Forêt de Bébour, track from the "Gîte" to Caverne Dufour, S 2104.686" E 55 $31.535^{\prime}, 2030$ m, low shrub with Erica arborescens, E. montana and Phylica nitida with large open wet places, 1 vi 2008, M. Brand, E. Sérusiaux, P. van den Boom s. n. (LG).

\section{Key for Melanotopelia species}

1 Ascomata $0.6-1.0 \mathrm{~mm}$ diam., with a wide ostiole $(0 \cdot 1-0.3 \mathrm{~mm})$ when mature; ascomata surface with 5-6 longitudinal wrinkles which are conspicuously white pruinose when young; thallus producing substances in the stictic acid group; Tasmania . . . . . . . . . . . . . . . M. rugosa

Ascomata smaller, rarely exceeding $0.5 \mathrm{~mm}$ diam., with a punctiform ostiole (50 $100 \mu \mathrm{m}$ diam.); ascomata without pronounced wrinkles or white pruina . . . . 2

2(1) Thallus producing substances in the stictic acid group; Africa (Rwanda and La Réunion) . . . . . . . . . . . . . . M. africana Thallus producing protocetraric acid; Western North America . . M. toensbergii 
We thank the Institut de Recherche Scientifique et Technologique (IRST) in Butare, the Projet de Conservation de la Forêt de Nyungwe (PCFN) and the Bureau de Jumelage Rhénanie-Palatinat-Rwanda for logistical support during field trips in Rwanda. We are grateful to the Rwanda Office for Tourism and National Parks (ORTPN) for collection and export permits, and especially for their guidance and support in the Park of Nyungwe. We also thank our friends Mr Bonny Dumbo (République Démocratique du Congo) and Dr Alain Hambuckers (University of Liège) for their companionship and support during field work in Rwanda. Our field trip in La Réunion was made possible by a collection permit provided by the Parc National de la Réunion, through the courtesy of Mr B. Lequette; we also benefited from help by Mr J. M. Pausé (Parc National), Dr Cl. Ah-Peng and Prof. D. Strasberg of the Université of La Réunion in Saint-Denis; we thank them all very warmly. We also thank our colleagues and friends, Drs A. Aptroot, K. Kalb, G. Kantvilas (HO) and T. Tønsberg (BG) for the loan or gift of most valuable collections and for interesting suggestions. Finally, we wish to thank very warmly both referees for their most valuable comments and suggestions.

\section{REFERENCES}

Aptroot, A., Diederich, P., Sérusiaux, E. \& Sipman, H. J. M. (1997) Lichens and Lichenicolous Fungi from New Guinea. Bibliotheca Lichenologica 64: 1-220.

Breuss, O. (2000) Topeliopsis toensbergii (Lichens, Thelotremataceae) new to Canada. Evansia 17: 90.

Coppins, B. J. \& Aptroot, A. (2008) New species and combinations in The Lichens of the British Isles. Lichenologist 40: 363-374.

Ewango, C. E. N. (2002) Flore et végétation de la forêt naturelle de Nyungwe, Rwanda. Systematics and Geography of Plants 71: 1009-1015.

Fischer, E., Dhetchuvi, J.-P. \& Ntaganda, C. (2003) A new species of Impatiens (Balsaminaceae) from Nyungwe Forest, Rwanda. Systematics and Geography of Plants 73: 91-101.

Fischer, E. \& Killmann, D. (2008) Illustrated Field Guide to the Plants of Nyungwe National Park, Rwanda.
Koblenz: Geographical Colloquia, Series Biogeographical Monographs 1.

Frisch, A. (2006) The lichen family Thelotremataceae in Africa. A revision with special consideration of the taxa from Cameroon and Tanzania. Bibliotheca Lichenologica 92: 3-370.

Frisch, A. \& Kalb, K. (2006a) A monograph of Thelotremataceae with a complex structure of the columella. Bibliotheca Lichenologica 92: 371-516.

Frisch, A. \& Kalb, K. (2006b) The lichen Topeliopsis, additions and corrections. Lichenologist 38: 37-45.

Kalb, K. (2001) The lichen genus Topeliopsis in Australia and remarks on Australian Thelotremataceae. Mycotaxon 79: 319-328.

Kantvilas, G. \& Vĕzda, A. (2000) Studies on the lichen family Thelotremataceae in Tasmania. The genus Chroodiscus and its relatives. Lichenologist 32: 325-357.

Mangold, A., Martín, M. P., Lücking, R. \& Lumbsch, H. T. (2008a) Molecular phylogeny suggests synonymy of Thelotremataceae within Graphidaceae (Ascomycota: Ostropales). Taxon 57: 476-486.

Mangold, A., Martín, M. P., Kalb, K., Lücking, R. \& Lumbsch, H. T. (2008b) Molecular data show that Topeliopsis (Ascomycota, Thelotremataceae) is polyphyletic. Lichenologist 40: 39-46.

Orange, A., James, P. W. \& White, F. J. (2001) Microchemical Methods for the Identification of Lichens. London: British Lichen Society.

Staiger, B. (2002) Die Flechtenfamilie Graphidaceae. Studien in Richtung einer natürlicheren Gliederung. Bibliotheca Lichenologica 85: 1-526.

Staiger, B., Kalb, K., Grube, M. (2006) Phylogeny and phenotypic variation in the lichen family Graphidaceae (Ostropomycetidae, Ascomycota). Mycological Research 110: 765-772.

Strasberg, D., Rouget, M., Richardson, D. M., Baret, S., Dupont, J. \& Cowling, R. M. (2005) An assessment of habitat diversity and transformation on $\mathrm{La}$ Réunion island (Macarenes Islands, Indian Ocean) as a basis for identifying broad-scale conservation priorities. Biodiversity and Conservation 14: 3015-3032. 